НАУКОВИЙ ВІСНИК НВВВСНого нащонАльного унввереител РИнаРНӦ̈ МЕДИИИНИ ТА БОТЕКНОЛО імені С.3. гжищьког Scientific messenger of L wiv National Univer
Veterinary Medicine and Biotechnologie

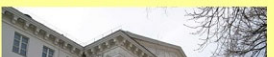

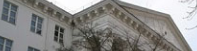
III 19 贯 We

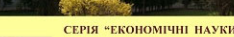

EERES Том 21 № 93 2019

Науковий вісник Дьвівського національного університету ветеринарної медицини та біотехнологій імені С.3. Гжицького. Серія: Економічні науки

\author{
Scientific Messenger of Lviv National University \\ of Veterinary Medicine and Biotechnologies. \\ Series: Economical Sciences
}

UDC 338.43

\title{
Problems of state regulation of agriculture of Ukraine
}

\author{
S. Poperechnyi, O. Tarnavska
}

Stepan Gzhytskyi National University of Veterinary Medicine and Biotechnologies Lviv, Ukraine

Article info

Received 09.09.2019

Received in revised form 08.10 .2019

Accepted 09.10.2019

Stepan Gzhytskyi National University of Veterinary Medicine and Biotechnologies Lviv, Pekarska Str., 50, Lviv, 79010, Ukraine.

Tel.: +38-067-253-32-67 E-mail: stepany2008@ukr.net
Poperechnyi, S., \& Tarnavska, O. (2019). Problems of state regulation of agriculture of Ukraine. Scientific Messenger of Lviv National University of Veterinary Medicine and Biotechnologies. Series: Economical Sciences, 21(92), 42-46. doi: 10.32718/nvlvet-e9309

The problems of state support of agriculture of Ukraine are analyzed. Scientific publications are dominated by criticism of existing support systems without conventional approaches to improving it. Even the interpretation of the concept of "state support" is debatable. The development of state support programs is complicated by the unformed market environment, the high level of monopolization of the agricultural procurement sector, and the difficulty of bringing small producers to target market segments. It is concluded that because of this, the possibility of creating private farms without their registration as legal entities is not realized. There has been a tendency for the emergence and accelerated development of particularly large farms focused on production for the export of raw materials while aggravating the social problems of the village. Only by government support will the negative trends in cattle reductions be offset. It is proposed to increase the effectiveness of state support programs by creating self-regulatory vertical marketing systems, in which the interests of all participants of these systems, ensuring their sustainable development, will be coordinated without direct state administrative intervention. Organizationally, it is easiest to create vertical marketing systems based on the initiative of existing processing plants, for which this is a way of procuring the required amount of raw materials with specified characteristics. Such raw materials can produce competitive products both domestically and internationally. Public financial support for such systems will ensure that their processes of origin and development are intensified. The organization's discussion on the cooperative principles of small processing is critically evaluated. It is shown that the main advantage of organizing such processing is to overcome market monopolization, to ensure without price interference stabilization of prices and their formation at a level acceptable to all members of the cooperative association. The risk of expected price uncertainty is reduced and bank loans may be attracted accordingly. Business plans for the development of individual enterprises and industries can be developed based on the expected price. The development of state targeted programs for agricultural development is simplified. Direction of state targeted programs of agricultural development and achievement of strategic goals, orientation to the data of the purpose of individual economic entities implies constant research and forecasting of market trends. Even large agricultural enterprises or business associations cannot carry out such research on their own. They provide for taking into account the expected values of macroeconomic indicators, and taking into account the international integration of Ukraine and the situation of the international market. Such research by state institutions, dissemination of information on the results of research, bringing information to all participants of the agrarian market is more important state support than direct state financial support.

Key words: state support for agriculture, financial support, information support, self-regulatory economic systems, state support for farms, state support for cooperative servicing in agriculture.

\section{Проблеми державної підтримки сільського господарства України}

\author{
С.І. Поперечний, О.Б. Тарнавська
}

Львівський національний університет ветеринарної медицини та біотехнологій імені С.3. Гюицького, м. Львів, Україна 
Аналізуються проблеми державної підтримки сільського господарства України. У наукових виданнях переважає критика існуючих систем підтримки без загальноприйнятих підходів до ї̈ удосконалення. Дискусійним є навіть тлумачення поняття “державна підтримка”. Розробка програм державної підтримки ускладнюється несформованим ринковим середовищем, високим рівнем монополізації сфери закупівель сільськогосподарської продукиії, проблемністю вивести невеликими виробниками продукцію на иільові сегменти ринку. Зроблено висновок, щуо через ие не реалізуються можливості створення особистими селянськими господарствами фермерських господарств без їх реєстраџї як юридичних осіб. Намітилась тенденція виникнення та прискореного розвитку особливо великих господарств, зорієнтованих на виробництві для експорту сировини при посиленні соціальних проблем села. Лише частково державною підтримкою нейтралізуються негативні тенденції скорочення поголів'я великої рогатої худоби. Запропоновано посилювати результативність програм державної підтримки створенням саморегулівних вертикальних маркетингових систем, у яких без прямого державного адміністративного втручання узгоджуватимуться інтереси усіх учасників циих систем, щзо забезпечувати їх сталий розвиток. Організаційно найпростіше створювати вертикальні маркетингові системи на основі ініціативи існуючих переробних підприємств, для яких ие є способом заготівель необхідної кількості сировини з обумовленими ознаками. 3 такої сировини може вироблятись конкурентоспроможна як на внутрішньому, так $i$ на зовнішньому ринку продукція. Державна фінансова підтримка таких систем забезпечуватиме активізацію процесів їх виникнення та розвитку. Критично оиінюється дискусійність організачії на кооперативних засадах малої переробки. Показано, щчо основна перевага організації такої переробки полягає у подоланні монополізації ринку, забезпеченні без державного втручання стабілізацї цін і їх формування на рівні, прийнятному для усіх учасників кооперативного об 'єднання. Зменшується ризик очікуваної цінової невизначеності і відповідно можливе залучення банківських кредитів. Можна розробляти обтрунтовані з урахуванням очікуваної ціни бізнес-плани розвитку окремих підприємств та галузей. Спрощується розробка державних иільових програм розвитку сільського господарства. Спрямування державних иільових програм розвитку сільського господарства та досягнення стратегічних иілей, орієнтація на дані цілі окремих суб'єктів господарювання передбачає постійне дослідження і прогнозування ринкових тенденцій. Такі дослідження самостійно не можуть здійснювати навіть великими сільськогосподарськими підприємствами чи об'єднаннями підприємств. Вони передбачають урахуваннями очікуваних значень макроекономічних показників, а з урахуванням міжнародної інтеграчії України і кон'юнктури міжнародного ринку. Здійснення таких досліджень державними інституціями, поширення інформації за результатами досліджень, доведення інформачї до усіх учасників аграрного ринку є вагомішою державною підтримкою, ніж пряма державна фінансова підтримка.

Ключові слова: державна підтримка сільського господарства, фінансова підтримка, інформаційна підтримка, саморегулівні економічні системи, державна підтримка фермерських господарств, державна підтримка обслуговуючих кооперативів у сільському господарстві.

\section{Ветуп}

Проблеми державної підтримки сільського господарства складні і багатопланові. Це обумовлюється невизначеністю загальної стратегії розвитку галузі, прийнятної для неї організаційної структури, поширенням запозичених зарубіжних підходів щодо такої підтримки без належного урахування актуальних завдань вітчизняного сільського господарства, на вирішення яких спрямовується підтримка. Значна кількість публікацій 3 цієї проблеми поєднується 3 несформованістю загальноприйнятих підходів навіть до розуміння і тлумачення поняття “державна підтримка”. Д.В. Лічак застерігає від необгрунтованого ототожнення понять “державна підтримка" та “державна допомога”. На думку автора до поняття підтримки слід включати державні заходи фінансового, організаційного, інформаційного та адміністративного порядку (Lichak, 2009). Я. Петруненко, категорично не заперечуючи відмінностей у трактуванні сутності понять “державна допомога” та “державна підтримка”, все ж визнає їх певну змістову подібність. На його думку відмінності полягають у семантиці цих понять (Petrunenko, 2018). У економічній літературі значна увага звертається на приведення рівня, форм $\mathrm{i}$ спрямування державної підтримки сільського господарства у відповідність до вимог міжнародних актів, яких Україна зобов'язалась дотримуватись після набуття членства у COT (Lutsenko, 2015), але поза увагою залишаються можливості застосування принципу асиметрії і використання у перехідному періоді країнами, які набули членство у СОТ за останні роки підходів, відмінних від тих, які використовуються колишніми членами.
Метою досліджень $є$ аналіз та обгрунтування доцільних і прийнятних для вітчизняного сільського господарства форм державної підтримки.

Для досягнення мети вирішувались завдання виявити причини недостатньої результативності програм державної підтримки, здійснити порівняльний аналіз різних форм державної підтримки, обгрунтувати точки прикладання зусиль та фокусування програм підтримки на вирішенні найвагоміших проблем сільського господарства.

\section{Матеріал і методи досліджень}

Дослідження здійснювались на основі застосування загальноприйнятих методів. На основі монографічного методу вивчались проблеми, на які доцільно спрямовувати програми державної підтримки; економіко статистичні методи використано для аналізу тенденцій, які складаються за результатами такої підтримки.

\section{Результати та їх обговорення}

Ринкове середовище у сільському господарстві складне і динамічне. Воно характеризується неналежною сформованістю інфраструктури аграрного ринку, основними функціями якої є генерування цін та товаропотоків. Характерною особливістю $є$ високий рівень монополізації сфери закупівель сільськогосподарської продукції, проблемність виведення на ринок продукції невеликими виробниками, для яких самостійне виведення продукції на ринок є організаційно ускладненим i дорогим у розрахунку на одиницю продукції. При цьому таке ринкове середовище проблемно вивчати і тим більше прогнозувати. В таких 
умовах неможливо розробляти бізнес-плани та маркетингові програми. Не можуть бути ефективними i програми державної підтримки сільського господарства. Проблема посилюється невизначеністю чітких стратегічних цілей розвитку аграрного сектора економіки, його організаційні побудови.

Тривала державна підтримка фермерських господарств поєднується 3 скороченням їх кількості. За 2016-2018 роки чисельність фермерських господарств в Україні скоротилась 333682 до 33164. При цьому майже не використовуються можливості створення фермерських господарств сімейного типу, визначені доповненнями до Закону України "Про фермерські господарства”, що організаційно спрощує процедуру реєстрації фермерського господарства. Намітилась тенденція поляризації сільськогосподарських суб'єктів господарювання за розмірами - поєднання дрібних селянських господарств 3 особливо великими за розмірами сільськогосподарськими підприємствами голдингового типу при витісненні середніх за розмірами організаційних форм. Крім проблем адаптації невеликих суб'єктів господарювання до ринкового середовища цьому сприяє спрямування державної фінансової підтримки фермерських господарств. Якщо до 2018 року фінансову підтримку могли отримувати фермерські господарства, площа сільськогосподарських угідь яких складала до 500 га, то відповідно до положень постанови Кабінету Міністрів України від 24 жовтня 2018 року № 911 "Про внесення змін до Порядку використання коштів, передбачених у державному бюджеті для надання фінансової підтримки розвитку фермерських господарств” площа сільськогосподарських угідь не обмежується. Намітилась тенденція збільшення кількості формально фермерських господарств, насправді господарств плантаторського типу в рослинництві і заводського у тваринництві. Такі господарства переважно орієнтуються на зовнішній ринок, де ціни вищі та стабільніші, ніж на внутрішньому ринку. Вони, як правило, зареєстровані у містах, де сплачують місцеві податки та збори, посилюючи соціальні проблеми сільських населених пунктів. Акумулюючи у таких господарствах значний капітал та використовуючи довершені технічні засоби їх власники до роботи не залучають жителів села, посилюючи і без цього високий рівень безробіття. При цьому такі господарства спеціалізуються на виробництві зерна, насіння соняшнику та ріпаку. Використовуючи переваги активізації міжнародних інтеграційних процесів та забезпечуючи конкурентні переваги за рахунок природних чинників, насамперед родючих чорноземів, такі господарства постійно збільшують обсяги експорту продукції. Цим забезпечуються валютні надходження і підтримання валютного курсу національної грошової одиниці, але зростають обсяги імпорту переробленої продукції. Для подолання тенденції посилення імпортозалежності доцільно державну підтримку спрямовувати на стимулювання створення і розвитку різних за організаційними формами вертикальних маркетингових систем, у яких на основі узгодження вимог до обсягів виробництва продукції, ïi якісних ознак та ціни вироблятиметься i пропонуватиметься продукція відповідно до вимог споживачів, що відносяться до різних цільових сегментів ринку. У таких структурах конкурентні переваги забезпечуються ознаками і властивостями продукції. Така продукція може пропонуватись за вищими цінами, що забезпечуватиме належний прибуток. До складу вертикальних маркетингових систем можуть входити різні за розмірами та організаційними формами сільськогосподарські підприємства і селянські господарства. Без надмірного укрупнення невеликі за розмірами господарства можуть забезпечувати такий же прибуток на капітал, як і великі голдинги. Ринок повніше насичуватиметься різноманітною продукцією i повніше задовольнятимуться потреби споживачів, віднесених до різних сегментів ринку.

Трансформація селянських господарств у фермерські здійснюватиметься лише якщо це буде економічно вигідно головам та членам існуючих селянських господарств. Як свідчить досвід спрощення організаційної процедури реєстрації фермерських господарств не $є$ основним чинником, що сприяє їх виникненню та розвитку. У більшій мірі стимулюватимуть набуття цими господарствами статусу фермерських та їх трансформацію у товарно орієнтовані господарства ринкового типу можливості виробництва та виведення на ринок конкурентоспроможної продукції.

Вертикальні маркетингові системи є саморегулівними організаціями. Їх поширення призводитиме до послаблення необхідності постійного втручання державних органів у регулювання міжгалузевих відносин. Привабливість таких систем для фермерських господарств визначається можливістю забезпечення прибуткового функціонування. Залучення програм державної підтримки новостворених фермерських господарств посилюватиме таку привабливість і забезпечить подолання хронічної проблеми поєднання державної фінансової підтримки фермерських господарств та скорочення або дуже млявого в окремі роки збільшення їх кількості.

Організаційно найпростіше створювати вертикальні маркетингові системи на основі ініціативи існуючих переробних підприємств, для яких це є способом заготівель необхідної кількості сировини з обумовленими ознаками. 3 такої сировини може вироблятись конкурентоспроможна як на внутрішньому, так і на зовнішньому ринку продукція. Державна фінансова підтримка таких систем забезпечуватиме активізацію процесів їх виникнення та розвитку. Все ж володіючи монополією на окремих регіональних ринках переробні підприємства ніколи добровільно від неї не відмовляться. Як свідчить набутий в Україні досвід навіть в умовах дефіциту сировини для переробки та ризику банкрутства через це переробні підприємства проявляють монопольні тенденції у сфері ціноутворення.

Загальнопоширеним у світовій практиці способом подолання монополізації сфери закупівель сільськогосподарської продукції є створення іiі виробниками збутових кооперативів. В Україні уже тривалий час 3 орієнтацією на створення і розвиток таких кооперативів розробляються і приймаються державні регуляторні акти, спрямовуються організаційні зусилля державних органів управління сільським господарством, 
здійснюється державна фінансова підтримка. Фінансова підтримка спрямовується на сплату пайових внесків потенційними учасниками обслуговуючих кооперативів, часткову компенсацію вартості придбаних обслуговуючими кооперативами технічних засобів та обладнання. Очевидним є чітке спрямування державної підтримки обслуговуючих кооперативів 3 урахуванням створення умов для розвитку фермерських господарств. Фінансова підтримка надається лише тому обслуговуючому кооперативу, до складу якого входить хоч би одне фермерське господарство.

Створенням i функціонуванням обслуговуючих кооперативів долаються монопольні тенденції окремих учасників аграрного ринку лише за умови організації у кооперативних формуваннях сфери переробки сільськогосподарської продукції та реалізації продуктів переробки споживачам. Без цього лише частково удосконалюються логістичні операції в системі збуту сільськогосподарської продукції. Дискусійність щодо організації на кооперативних засадах малої переробки $€$ безпідставною. Основна перевага організації такої переробки полягає у подоланні монополізації ринку, забезпеченні без державного втручання стабілізації цін і їх формування на рівні, прийнятному для усіх учасників кооперативного об'єднання. Зменшується ризик очікуваної цінової невизначеності і відповідно можливе залучення банківських кредитів. Можна розробляти обгрунтовані з урахуванням очікуваної ціни бізнес-плани розвитку окремих підприємств та галузей. Спрощується розробка державних цільових програм розвитку сільського господарства. Такі програми можна розробляти з орієнтацією на підвищення конкурентоспроможності сільськогосподарського виробництва, нарощування його обсягів, поліпшення якості і безпечності сільськогосподарської продукції (Kontseptsiia Derzhavnoi tsilovoi prohramy..., 2019). Без цього переважно використовуватимуться малоефективні в умовах ринкових відносин адміністративні методи, недостатньо акцентовані на дрібнотоварному секторі, розвиток якого є передумовою збалансованого розвитку сільської місцевості (Kontseptsiia Derzhavnoi tsilovoi prohramy..., 2019).

Спрямування державних цільових програм розвитку сільського господарства та досягнення стратегічних цілей, орієнтація на дані цілі окремих суб'єктів господарювання передбачає постійне дослідження i прогнозування ринкових тенденцій. Такі дослідження самостійно не можуть здійснювати навіть великі сільськогосподарськими підприємствами чи об'єднаннями підприємств. Вони передбачають урахуваннями очікуваних значень макроекономічних показників, а з урахуванням міжнародної інтеграції України і кон'юнктури міжнародного ринку. Здійснення таких досліджень державними інституціями, поширення інформації за результатами досліджень, доведення інформації до усіх учасників аграрного ринку є вагомішою державною підтримкою, ніж пряма державна фінансова підтримка. Така інформація у першу чергу необхідно виробникам продукції, що відносяться до галузей з тривалою окупністю капіталу - молочного і м'ясного скотарства. Невизначеність ринкових тенденцій $є$ основним стримуючим чинни- ком розвитку цих галузей. Загальна тенденція зменшення поголів'я великої рогатої худоби не долається спрямуванням державної фінансової підтримки розвитку скотарства. За 2014-2018 роки поголів'я корів у всіх категоріях господарств скорочено 32262,7 до 1949,4 тисяч голів, а виробництво молока відповідно скоротилось 311133 до 10064 тисяч тонн (рис. 1). При цьому в 2018 році 75,6\% із загального поголів'я корів утримувалось в особистих селянських господарствах, які переважно не мають товарні орієнтації.

Молоко та молочні продукти за незначним виключенням відносяться до соціально значимих продовольчих товарів першої необхідності. Попит на них залишається стійким навіть в умовах кризових явищ та зниження доходів споживачів. Через зменшення обсягів виробництва молока вітчизняні виробники не можуть використати сприятливі можливості виведення молочних продуктів на зовнішній ринок. Вони втрачають внутрішній ринок. При цьому проблеми виведення продукції на зовнішній ринок та втрати позицій на внутрішньому ринку посилюються низькою якістю молока для переробки.

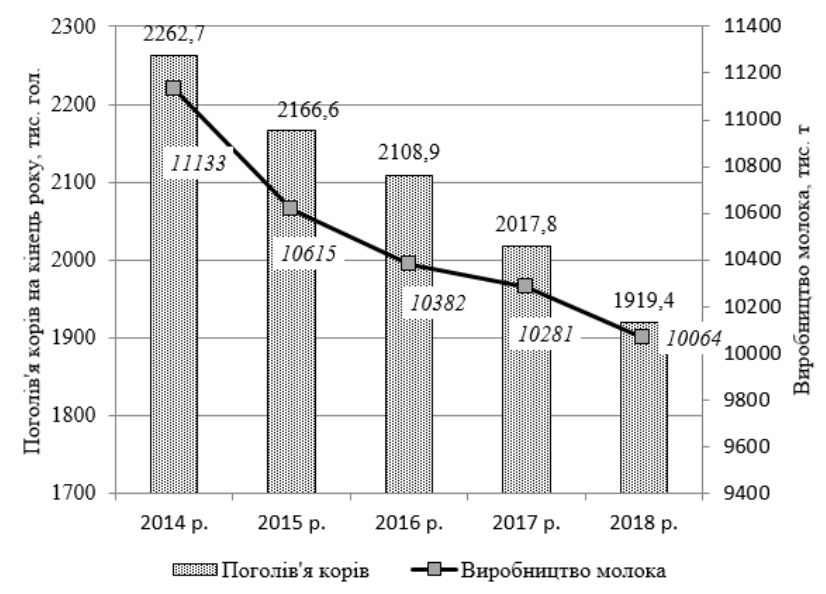

Рис. 1. Поголів’я корів та виробництво молока в Україні

В особистих селянських господарствах, як правило, використовуються технології, на основі яких не може бути виготовлене молоко гатунку “Екстра", а відповідно до чинних в СС вимог тільки таке молоко придатне на харчові цілі. Відповідно широкомасштабна підтримка молочного скотарства лише частково стримує загальні тенденції скорочення обсягів виробництва продукції, втрати внутрішнього ринку та неспроможності збільшення частки вітчизняних виробників на зовнішніх ринках. Необхідне фокусування підтримки на ключових точках подолання проблем. У молочному скотарстві пряму державну фінансову підтримку слід спрямовувати на розробку типових бізнес-планів виробництва молока гатунку "Екстра" та компенсацію до 90\% вартості придбаних телиць і обладнання з використанням якого може вироблятись така сировина. Для контролю за цільовим використанням державних коштів придбані за них засоби до виходу на проектну потужність можуть перебувати у державній власності. Після цього вони можуть бути 
передані існуючим молокопереробним підприємствам або обслуговуючим кооперативам, які володіють обладнанням для переробки молока, придатним для виробництва конкурентоспроможних на зовнішньому ринку молочних продуктів. Це ще один спосіб формування саморегулівних економічних систем, які завдяки узгодженості інтересів усіх учасників, що входять до їх складу забезпечуватимуть сталий розвиток без прямого адміністративного втручання державних органів управління сільським господарством. Крім прямого впливу на збільшення обсягів виробництва продукції та посилення конкурентних позицій вітчизняних виробників це матиме вплив на формування позитивного досвіду ефективного підприємництва у сфері виробництва і переробки молока та сприятиме залученню для таких цілей децентралізованих коштів.

\section{Висновки}

Проблеми державної підтримки сільського господарства активно дискутуються у наукових виданнях. Переважає критика існуючих підходів без сформованих загальноприйнятих рекомендацій щодо удосконалення такої підтримки. Організаційні зусилля державних органів управління сільським господарством та кошти державної фінансової підтримки, що за останні роки спрямовуються на розвиток фермерських господарств, становлення обслуговуючих кооперативів, а також збільшення поголів'я великої рогатої худоби не забезпечили очікуваних результатів. Вони лише частково нейтралізують вагоміший вплив монопольних тенденцій закупівельних організацій. Через це пряму державну фінансову підтримку слід фокусувати на становленні та розвитку саморегулівних вертикальних маркетингових систем, які можна формувати на основі державного дотування будівництва переробними підприємствами ферм для виробництва тваринницької сировини, придатної для виготовлення конкурентоспроможної на зовнішньому ринку продукції. Без цього проявлятимуться лише негативні в умовах міжнародних інтеграційних процесів тенденції втрати вітчизняними виробниками конкурентних позицій. Прийнятною є пряма державна фінансова підтримка організації в обслуговуючих кооперативах сфери переробки продукції. У мінливому ринковому середовищі необхідна державна інформаційна підтримка, що здійснюється за результатами дослідження і прогно- зування ринку, доведення результатів таких досліджень до суб'єктів господарювання. Це забезпечить розробку ними обгрунтованих бізнез-планів, зменшення ризиків, раціональніше використання коштів прямої державної фінансової підтримки

\section{References}

Kontseptsiia Derzhavnoi tsilovoi prohramy rozvytku ahrarnoho sektoru ekonomiky na period do 2022 roku. Kabinet Ministriv Ukrainy (data zvernennia: 1.10.2019) URL: https://zakon.rada.gov.ua/laws/ show/1437-2015-\%D1\%80 (in Ukrainian).

Latynin, M.A., \& Zaskalkina, O.M. (2016). Otsiniuvannia mekhanizmiv derzhavnoho rehuliuvannia instytutsionalnoho seredovyshcha $\mathrm{v}$ ahrarnomu sektori ekonomiky Ukrainy. Publichne upravlinnia: teoriia ta praktyka, 2(16), 1-14. http://www.dridu.dp.ua/zbirnik/ 2016-02(16)/15.pdf (in Ukrainian).

Lichak, D.V. (2009). Problemy vyznachennia poniattia "derzhavna pidtrymka subiektiv hospodariuvannia". Aktualni problemy derzhavy i prava, 50, 403-411. http://nbuv.gov.ua/UJRN/apdp_2009_50_64 (in Ukrainian).

Lutsenko, O.A. (2015). Derzhavna pidtrymka silskoho hospodarstva krain YeS: dosvid dlia Ukrainy. Visnyk Kharkivskoho natsionalnoho tekhnichnoho universytetu silskoho hospodarstva imeni Perta Vasylenka, 161, 213-220. http://nbuv.gov.ua/UJRN/ Vkhdtusg_2015_161_27 (in Ukrainian).

Petrunenko, Ya. (2018). Poniattia derzhavnoi pidtrymky subiektiv hospodariuvannia yak zasobu zabezpechennia efek-tyvnoho vykorystannia biudzhetnykh koshtiv. Hospodarske pravo i protses, 6, 110-115. http://pgp-journal.kiev.ua/archive/2018/6/ 20.pdf (in Ukrainian).

Seheda, S.A. (2016). Derzhavne rehuliuvannia ahrarnoprodovolchoho rynku v umovakh chlenstva Ukrainy $\mathrm{v}$ SOT. Ekonomika i suspilstvo, 2, 175-180. http://economyandsociety.in.ua/journal/2_ukr/32.pdf (in Ukrainian).

Shpak, Yu.V. (2010). Problemy derzhavnoho rehuliuvannia ekonomichno-bezpechnoho rozvytku ahropromyslovoho vyrobnytstva. Derzhavne upravlinnia: udoskonalennia ta rozvytok. 2010. № 4.11. URL: http://www.dy.nayka.com.ua/?op=1\&z=208 (data zvernennia 1.10.2019) (in Ukrainian). 